\title{
Influence of Diadema antillarum populations (Echinodermata: Diadematidae) on algal community structure in Jardines de la Reina, Cuba
}

\author{
Félix Martín Blanco ${ }^{1}$, Lídice Clero Alonso ${ }^{1}$, Gaspar González Sansón ${ }^{2}$ \& Fabián Pina Amargós ${ }^{1}$ \\ 1. Centro de Investigaciones de Ecosistemas Costeros, Ministerio de Ciencia, Tecnología y Medio Ambiente. Cayo \\ Coco, Morón, Ciego de Ávila, CP 69400, Cuba; felix.martin79@gmail.com, fabian@ciec.fica.inf.cu, \\ 1clero@yahoo.es \\ 2. Centro de Investigaciones Marinas, Universidad de la Habana. Calle 16, \# 114 e/ 1ra y 3ra, Miramar, Playa, Ciudad \\ de La Habana, CP. 11300, Cuba; gaspargonzalez2001@yahoo.es
}

\author{
Received 10-VIII-2010. C Corrected 09-I-2011. Accepted 08-II-2011.
}

\begin{abstract}
The 1983-1984 mass mortality of Diadema antillarum produced severe damages on Caribbean reefs contributing to substantial changes in community structure that still persist. Despite the importance of Diadema grazing in structuring coral reefs, available information on current abundances and algal-urchin interactions in Cuba is scarce. We analyzed spatial variations in Diadema abundance and its influence on algal community structure in 22 reef sites in Jardines de la Reina, in June/2004 and April/2005. Urchins were counted in five $30 \times 2 \mathrm{~m}$ transects per site, and algal coverage was estimated in randomly located $0.25 \mathrm{~m}$ side quadrats (15 per site). Abundances of Diadema were higher at reef crests $\left(0.013-1.553 \mathrm{ind} / \mathrm{m}^{2}\right)$, while reef slope populations showed values up to three orders of magnitude lower and were overgrown by macroalgae (up to $87 \%$, local values). Algal community structure at reef slopes were dominated by macroalgae, especially Dictyota, Lobophora and Halimeda while the most abundant macroalgae at reef crests were Halimeda and Amphiroa. Urchin densities were negatively and positively correlated with mean coverage of macroalgae and crustose coralline algae, respectively, when analyzing data pooled across all sites, but not with data from separate habitats (specially reef crest), suggesting, along with historical fish biomass, that shallow reef community structure is being shaped by the synergistic action of other factors (e.g. fish grazing) rather than the influence of Diadema alone. However, we observed clear signs of Diadema grazing at reef crests and decreased macroalgal cover according to 2001 data, what suggest that grazing intensity at this habitat increased at the same time that Diadema recruitment began to be noticeable. Furthermore, the excessive abundance of macroalgae at reef slopes and the scarcity of crustose coralline algae seems to be due by the almost complete absence of $D$. antillarum at mid depth reefs, where local densities of this urchin were predominantly low. Rev. Biol. Trop. 59 (3): 1149-1163. Epub 2011 September 01.
\end{abstract}

Key words: Diadema antillarum, algal community structure, algal-urchin relationships, hervibory, Jardines de la Reina, Cuba.

The 1983-1984 mass mortality of Diadema antillarum Philippi, 1845 in the Caribbean produced significant damages on many coral reefs of the region. Several reefs around the wider Caribbean became rapidly overgrown by macroalgae after depletion of this major herbivore (Hughes et al. 1985, Liddell \& Ohlhorts 1986, De Ruyter van Steveninck
\& Breeman 1987, Levitan 1988, Carpenter 1990) and experienced substantial changes in benthic community structure that still persist (Hughes 1994, Hughes et al. 1999, Aronson \& Precht 2000, 2006, Edmunds \& Carpenter 2001, Knowlton 2001, Bellwood et al. 2004, Carpenter \& Edmunds 2006, Mumby et al. 2006). The increasingly decline of reef corals 
in the absence of $D$. antilllarum emphasize the impact of limited functional redundancy of Caribbean reef ecosystems (Bellwood et al. 2004) and demonstrate that Caribbean reefs lost a key component of resilience at the time of Diadema die-off. Accordingly, the recovery of $D$. antillarum populations across the entire Caribbean during the last decade has been associated with decrease macroalgal cover and enhanced coral cover and recruitment (Aronson \& Precht 2000, Edmunds \& Carpenter 2001, Miller et al. 2003, Weil et al. 2005, Carpenter \& Edmunds 2006, Myhre \& AcevedoGutiérrez 2007) showing that a phase reversal from macroalgal to coral dominance could be possible if former levels of herbivory resume (Carpenter \& Edmunds 2006, Mumby 2009).

Although there are no historical records about the status of Diadema populations in Cuban reefs before die-off (only one paper about methodological aspects was published, Herrera-Moreno et al. 1981), and no scientific papers reported the consequences of the mortality in coral reefs, today it is well documented that several Cuban reefs are overgrown by macroalgae, which are generally more abundant than corals at shallow and mid depth reefs (Alcolado et al. 2001, Caballero \& Guardia 2003, Guardia et al. 2004a, b, 2006, Caballero et al. 2006, Clero-Alonso et al. 2006, Pina-Amargós et al. 2006). Fore reef habitats from Jardines de la Reina represent a clear example of macroalgal dominated/coral depauperate ecosystems; Pina-Amargós et al. (2006) reported mean cover of macroalgae of $32 \%$ and $58 \%$ at reef crests and reef slopes respectively and $<20 \%$ of coral cover at both habitats.

In spite of the importance of Diadema as a keystone species in structuring coral reefs, available information about population abundances and its influence on algal community structure in Cuban reefs is scarce. The most complete data come from surveys of the Atlantic and Gulf Rapid Reef Assessment (AGRRA) carried out at 199 reef sites around the Cuban archipelago from 1999 to 2003 (Alcolado et al . unpublished data), but little is discussed about algal-urchin interactions at surveyed reefs by the authors, which reassessed South Western Cuban sites corresponding to Los Canarreos Archipelago in 2007 (Alcolado et al. 2009) and only focused on the impact of hurricanes and coral diseases affecting studied reefs, neglecting the importance of algal-urchin interactions and the impact of a long period of reduced herbivory (urchins and fishes) despite an apparent recent recovery of Diadema in some reefs, as reported by the authors, and the enforcement of fish protection in Canarreos Marine Reserve. In a broader study, Williams \& Polunin (2001) analyzed relationships between algal cover and grazers at seven locations across the Caribbean including two areas in Cuban Western reefs, but their conclusions are limited to mid depth reefs $(12-15 \mathrm{~m})$, thus urchin grazing effects remain unclear in Cuban shallow reefs though Caballero et al. (2009) contribution, in which benthic community structure and urchin densities were studied closely at shallow and mid depth reefs from the North coast of Havana.

The present report analyzes spatial variations in population abundance of $D$. antillarum and its influence on algal community structure by exploring algal-urchin relationships (percent cover of algae vs densities of Diadema) and examining linked patterns of abundance of algal functional groups at different spatial scales within and adjacent to a Marine Reserve in Jardines de la Reina Archipelago, Cuba. We therefore expected that densities of $D$. antillarum would be negatively correlated with macroalgal cover and positively with algal turf and crustose coralline algae at fore reefs habitats, considering that because of Jardines de la Reina is located far from human settlements and two thirds of the archipelago constitute a No-Take Marine Reserve with an effective protection, the study area can be consider as a "quasi-pristine" zone where nutrient concentrations and fish assemblages have been not affected by human impacts, thus they are not responsible for macroalgal overgrowth. This assumption is supported by the results of Pina-Amargós et al. (2006) who reported average fish biomass inside the Marine Reserve of $152 \mathrm{~g} / \mathrm{m}^{2}$ at reef crests and $118 \mathrm{~g} / \mathrm{m}^{2}$ at reef 
slopes with local values of $220-380 \mathrm{~g} / \mathrm{m}^{2}$ and $240-270 \mathrm{~g} / \mathrm{m}^{2}$ respectively and those reported by González de Zayas et al. (2006) who pointed out that nutrient concentrations were into conformity with oligotrophic water standards reported for the Caribbean.

Surveys were part of a broader research to evaluate the effectiveness of the Marine Reserve on reef fish assemblages.

\section{MATERIALS AND METHODS}

Study area: The Archipelago of Jardines de la Reina is one of the four main groups of islands around Cuba and the best conserved of all. Stretching approximately $360 \mathrm{~km}$, it is formed by 661 keys, which are located in the South-central part of the Cuban shelf between the Gulf of Ana María and the Gulf of Guacanayabo (Fig. 1). The archipelago has three groups of keys, the most important one is that of "Las Doce Leguas" (The Twelve Leagues) located in its Westernmost end. In 1996 two thirds of the archipelago (about $950 \mathrm{~km}^{2}$ ) were declared as Zone Under Special Regime of Use and Protection (equivalent to the internationally known Marine Reserves, and so termed in this paper) by the Ministry of Fisheries and currently are pending approval as a National Park by the Cuban Government. This is the largest of the Caribbean Marine Reserves and its coral reefs are among the best preserved in the region (Appeldoorn \& Lindeman 2003). Several patch reefs exist to the North of the keys while the most important and well developed fringing reefs are found in the Southern side where the most conspicuous are reefs crests (1-3m depth), with large stands of

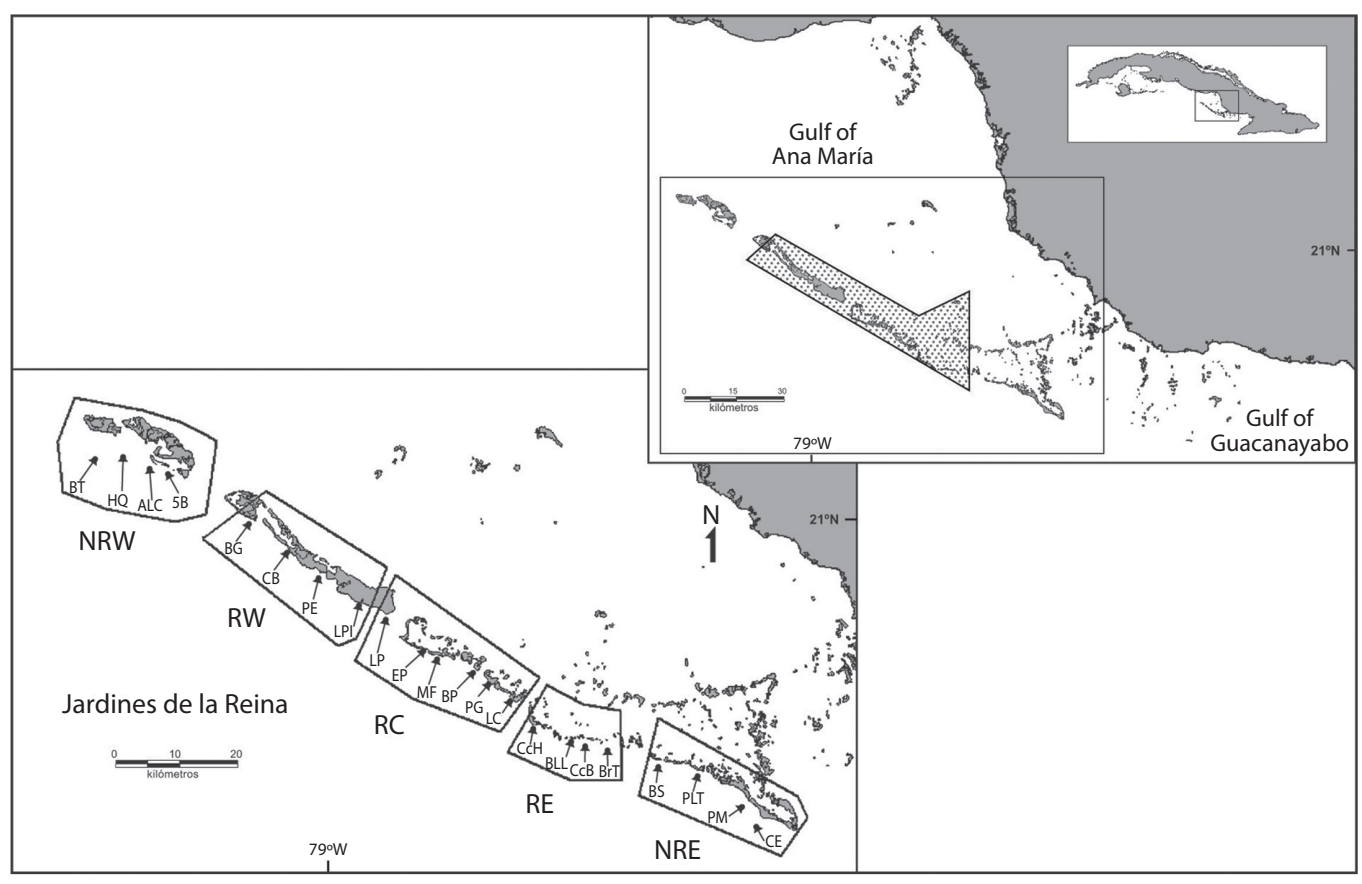

Fig. 1. Sampling sites in Jardines de la Reina, Cuba. Doted area represents the Zone Under Special Regime of Use and Protection. NRW=Non-reserve Western Zone, RW=Reserve Western Zone, RC=Reserve Central Zone, RE=Reserve Eastern Zone, NRE=Non-reserve Eastern Zone, BT=Bretón, HQ=Horqueta, ALC=Alcatraz, 5B=Cinco Balas, BG=Boca de Guano, $\mathrm{CB}=$ Caseta Blanca, $\mathrm{PE}=\mathrm{Punta}$ Escondida, LPI=Los Pinos, LP=La Puntica, EP=El Partido, MF=Mari Flores, BP=Boca de Piedra, PG=Piedra Grande, LC=Las Cruces, $\mathrm{CcH}=$ Cachiboca, BLL=Ballena, $\mathrm{CrB}=$ Carabinero, BrT=Bártolo, BS=Boca Seca, PLT=Peralta, PM=Punta Macao, CE=Cabeza del Este. 
dead Acropora palmata and some interspersed live colonies comprising the main component of three dimmensional structure, and reef slopes $(12-15 \mathrm{~m}$ the shallow reef slope and 20-30m the deep reef slope) with Siderastrea siderea and Agaricia agaricites as dominant species of coral assemblages.

Survey methodology: Surveys were conducted in the Southern fore reefs of Jardines de la Reina, in the group of keys of "Las Doce Leguas", in June 2004 and April 2005. Counts of $D$. antillarum were performed at each sampling time in five $30 \times 2 \mathrm{~m}$ transects located parallel to 10 reefs crests (specifically in the front part) and 21 shallow reef slopes, all distributed along 22 sampling sites (Fig. 1; see MartínBlanco et al. 2010 for GPS references of sites).

Percent cover of algae was estimated in $0.25 \mathrm{~m}$ side quadrats $(\mathrm{n}=15)$ which were randomly located at the same sites and habitats surveyed for urchins densities. Algal functional groups were categorized as macroalgae (fleshy, foliose and filamentous algae with frond $>1 \mathrm{~cm}$ tall plus Halimeda spp.), algal turf (mixed species assemblages of filamentous algae with canopy height $<1 \mathrm{~cm}$ ) and crustose coralline algae.

Data collected from sites were grouped in pre-determined zones, three within the Marine Reserve and two (Westward and Eastward) adjacent to the Marine Reserve (Fig. 1). The zone classifying criteria was based on the existing different degrees of protection in the Marine Reserve regarding that protection decreases from RC, RW, RE to NRW and NRE which show a higher human activity. That information was obtained previously to the design of this study, which is part of a broader research (Pina-Amargós 2008) carried out to evaluate the effectiveness of the Marine Reserve as mentioned in the Introduction section. Densities of $D$. antillarum recorded from reef crests were compared among zones at each sampling time using a one way ANOVA and the Student-Newman-Keuls test for post-hoc comparisons. Density data were transformed using the fourth root transformation as suggested by the log-mean $v s$ log-variance relationship
(Taylor's Law) for conformity to the assumptions of normality and variance homogeneity. No statistical analyses were performed with densities recorded from reef slopes to prevent erroneous results caused by a high proportion of zero values. Because of obvious differences in Diadema densities between habitats, statistical comparison was unnecessary.

Percent cover of each algal functional groups was compared among zones and between habitats with a two way balanced ANOVA (reef slope data from RE and NRE were not included in the analysis because comparable reef crests do not exist in shallow depths at corresponding sites from those zones) and the Student-Newman-Keuls test for posthoc comparisons at each sampling time. Data were transformed using the $\log _{10}(\mathrm{x}+1)$ transformation for conformity to statistical assumptions. An additional one way ANOVA was performed with all zones included to compare macroalgal coverage at reef slopes. Pearson's correlation coefficient was used to determine whether mean coverage of algal functional groups were correlated with mean densities of Diadema at each sampling time at two spatial scales (i.e. with data pooled across all reef crest and reef slope sites and data from reef crests and reef slopes by separate). All statistical analyses were performed using STATISTICA 6.0.

\section{RESULTS}

Urchin abundance: Abundances of $D$. antillarum were highest at reef crests during the study. Mean population densities were up to three orders of magnitude higher than those recorded at reef slopes (local values up to $1.553 \mathrm{ind} / \mathrm{m}^{2}$ at $\mathbf{L P}$ in April 2005). Average densities of Diadema varied significantly among zones at reef crests $\left(\mathrm{F}_{(1,28)}=36.434, \mathrm{p}<0.01\right.$, in June 2004; $\mathrm{F}_{(2,46)}=36.522, \mathrm{p}<0.01$, in April 2005; Fig. 2) and were significantly higher within the Marine Reserve at each sampling time (0.741ind $/ \mathrm{m}^{2}$ and $0.982 \mathrm{ind} / \mathrm{m}^{2}$ at $\mathbf{R C}$ in June 2004 and April 2005 respectively and 1.092ind/ $\mathrm{m}^{2}$ at $\mathbf{R W}$ in April 2005). Densities from reef slopes ranged from $0.010-0.070 \mathrm{ind} / \mathrm{m}^{2}$ in June 


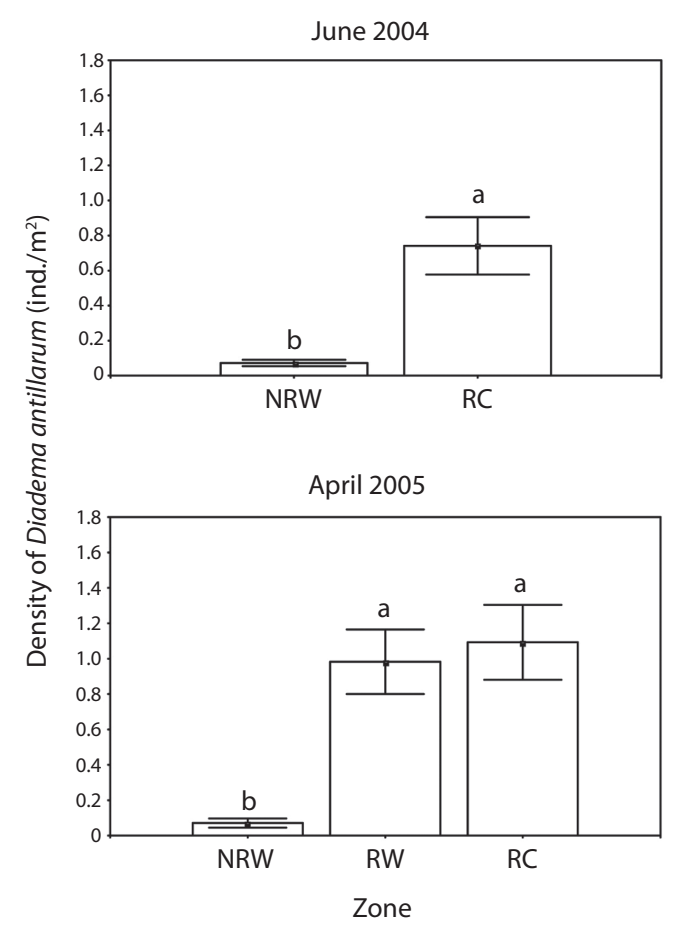

Fig. 2. Mean population densities (SE) of Diadema antillarum at reef crests across zones in Jardines de la Reina at each sampling time. Different letters indicate significant differences.

2004, while the lowest local value in April 2005 was $0.003 i n d / \mathrm{m}^{2}$ (see Table 2 in Martín-Blanco et al. 2010 for detailed information on abundance and distribution patterns). Diadema was found at only six of nine sites surveyed in June 2004 and absent at all in $42 \%$ of 19 sites surveyed in April 2005. The maximum site level density $\left(0.133 \mathrm{ind} / \mathrm{m}^{2}\right)$ occurred in April 2005, but there was only one site showing this value.

Community structure and algal-urchin relationships: Algal community structure varied significantly between habitats at each sampling time. Percent cover of macroalgae was significantly higher at reef slopes, where densities of $D$. antillarum were zero or near zero during the study $\left(\mathrm{F}_{(1,146)}=200.14\right.$, $\mathrm{p}<0.01$, in June 2004; $\mathrm{F}_{(1,201)}=236.35, \mathrm{p}<0.01$, in April 2005; Fig. 3 A, B). Mean coverage of macroalgae at reef slopes was $44 \%$ in June 2004 and 62\% in April 2005, with local values up to $67 \%$ and $87 \%$ respectively (Table 1 ). In contrast, the amount of substratum occupied by macroalgae at reef crests averaged $10 \%$ at each sampling time (Table 1). Except by percent cover of macroalgae at NRW zone which was higher than value from NRE zone in June 2004 and percent cover of macroalgae at $\mathbf{R W}$ zone which was higher than values from NRW and RE zones in April 2005 when comparing all zones at reef slopes (data not shown), no differences were found with any of the two ANOVA tests in macroalgal cover among zones during the study; the zone-habitat interaction was not significant either. Abundances of algal turf differed between habitats $\left(\mathrm{F}_{(1,146)}=50.73, \mathrm{p}<0.01\right)$ and between zones $\left(\mathrm{F}_{(1,146)}=62.82, \mathrm{p}<0.01\right)$ in June 2004, being significantly higher at reef crests (Fig. 3 C), pattern that was held across zones but was stronger at NRW zone in June 2004, as demonstrated by the significant zone-habitat interaction $\left(\mathrm{F}_{(1,146)}=30.42, \mathrm{p}<0.01\right)$. The pattern of higher coverage of algal turf at reef crests held in April $2005\left(\mathrm{~F}_{(1,201)}=12.30, \mathrm{p}<0.01\right.$; Fig. $\left.3 \mathrm{D}\right)$ and showed a significant zone-habitat interaction $\left(\mathrm{F}_{(2,201)}=10.15, \mathrm{p}<0.01\right)$ but mean values did not varied among zones. Percent cover of crustose coralline algae varied between habitats at each sampling time $\left(\mathrm{F}_{(1,146)}=373.61, \mathrm{p}<0.01\right.$, in June 2004; $\mathrm{F}_{(1,201)}=274.59, \mathrm{p}<0.01$, in April 2005) being higher at reef crests (Fig. 3 E, F). Mean values differed among zones only in June $2004\left(\mathrm{~F}_{(1,146)}=5.95, \mathrm{p}<0.05\right)$ and the zone-habitat interaction was not significant during the study. Algal community structure at reef crests, where Diadema was more abundant, was dominated by crustose coralline algae (mean values of 30\% in June 2004 and 46\% in April 2005, Table 1) while macroalgae occupied the major amount of substratum at reef slopes during the study. Macroalgal cover at reef slopes was dominated by Dictyota sp., Lobophora sp. and Halimeda sp. at each sampling time while the most abundant at reef crests were Halimeda sp. and Amphiroa sp. (Table 2). 

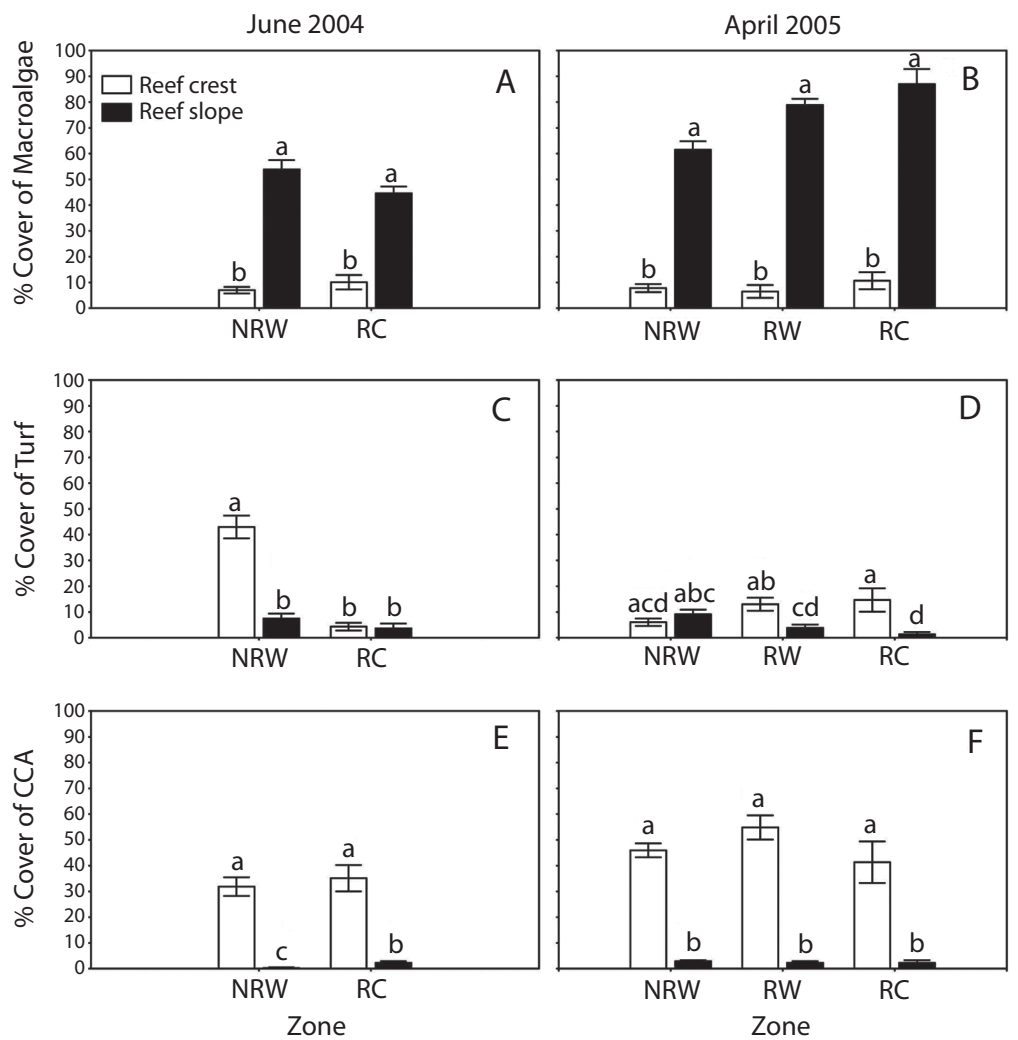

Fig. 3. Mean coverage (SE) of macroalgae $(A, B)$, algal turf $(C, D)$ and $C C A=$ crustose coralline algae $(E, F)$ at fore reef habitats across studied zones in Jardines de la Reina at each sampling time. Reef slope data from RE and NRE zones were not included because comparable reef crests do not exist at corresponding sites in shallow depths from those zones. Different letters indicate significant differences.

Correlations between percent cover of algal functional groups and the abundance of $D$. antillarum indicated a significant association among variables when analyzing data pooled across all sites. Densities of $D$. antillarum were negatively and positively correlated with mean coverage of macroalgae and crustose coralline algae, respectively, during the study (Fig. 4 A, B, E, F) while mean coverage of algal turfs showed no significant pattern of variation in relation to Diadema abundances at this spatial scale (Fig. 4 C, D). Partial correlations with data from reef crests and reef slopes by separate yielded no significant relationships among algal functional categories and
Diadema densities in most cases (Table 3). Only the percent cover of crustose coralline algae showed a significant positive relationship with the abundance of Diadema but Pearson's correlation coefficient was too low (Table 3).

\section{DISCUSSION}

Surveys from shallow and mid depth reefs in Jardines de la Reina showed that patterns of abundance of $D$. antillarum in the study zone are similar than those reported by Alcolado et al. (unpublished data) around Cuba. Data collected from reef slopes in Jardines de la Reina and those from other Cuban locations indicate a 


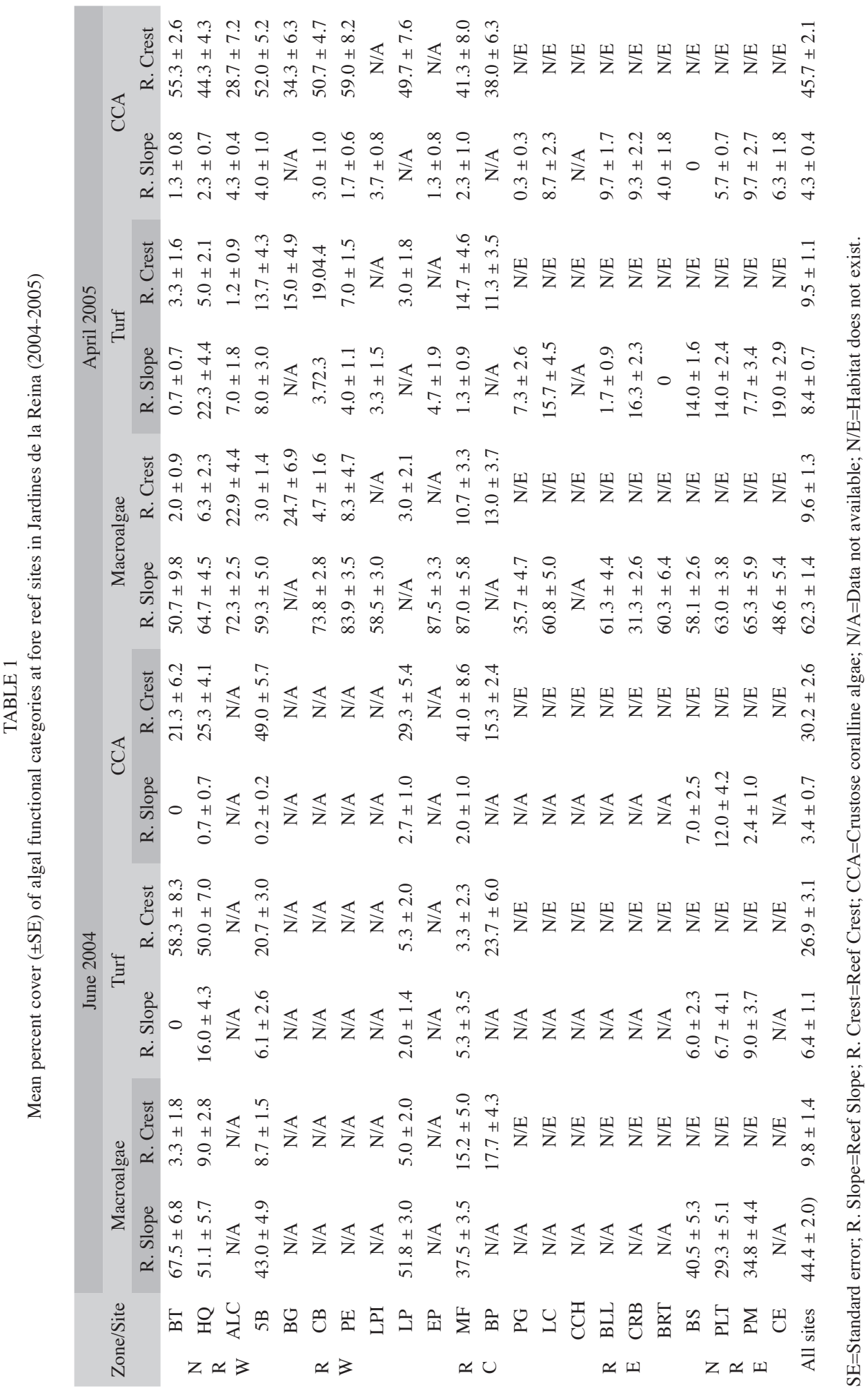


TABLE 2

Mean coverage $(\geq 0.3 \%)$ of macroalgal genera at fore reef sites in Jardines de la Reina (2004-2005)

\begin{tabular}{|c|c|c|c|c|c|}
\hline \multicolumn{3}{|c|}{ June 2004} & \multicolumn{3}{|c|}{ April 2005} \\
\hline Habitat (number of sites) & $\%$ cover & $\mathrm{SE}$ & Habitat (number of sites) & $\%$ cover & SE \\
\hline Reef slope (n=8) & & & Reef slope $(n=18)$ & & \\
\hline Dictyota & 24.9 & 5.5 & Dictyota & 29.9 & 7.5 \\
\hline Lobophora & 10.1 & 2.8 & Lobophora & 17.0 & 5.8 \\
\hline Halimeda. & 5.4 & 2.1 & Halimeda & 5.9 & 3.0 \\
\hline Stypopodium & 1.3 & 1.0 & Sargassum & 3.9 & 1.8 \\
\hline Sargassum & 0.9 & 0.3 & Jania & 1.5 & 1.6 \\
\hline Amphiroa & 0.7 & 0.5 & Amphiroa & 1.3 & 1.5 \\
\hline Anadyomene & 0.3 & 0.2 & Anadyomene & 1.2 & 1.0 \\
\hline Reef crest $(n=6)$ & & & Stypopodium & 0.8 & 0.9 \\
\hline Halimeda & 5.2 & 2.4 & Reef crest $(n=10)$ & & \\
\hline Amphiroa & 3.3 & 1.7 & Halimeda & 4.8 & 2.4 \\
\hline Laurencia & 0.4 & 0.3 & Amphiroa & 0.9 & 0.5 \\
\hline Dictyota & 0.3 & 0.2 & Laurencia & 0.6 & 0.3 \\
\hline Galaxaura & 0.3 & 0.2 & Dictyota & 0.5 & 0.2 \\
\hline & & & Galaxaura & 0.3 & 0.2 \\
\hline
\end{tabular}

$\mathrm{SE}=$ Standard error.

TABLE 3

Relationship between density of $D$. antillarum and percent cover of algal functional categories at reef habitats by separate in Jardines de la Reina (2004-2005)

\begin{tabular}{|c|c|c|c|c|c|c|}
\hline \multirow{2}{*}{ Habitat/Variables } & \multicolumn{3}{|c|}{ June 2004} & \multicolumn{3}{|c|}{ April 2005} \\
\hline & $\mathrm{r}(\mathrm{X}, \mathrm{Y})$ & $\mathrm{P}$ & $\mathrm{n}$ & $r(X, Y)$ & $\mathrm{p}$ & $\mathrm{n}$ \\
\hline \multicolumn{7}{|c|}{ Reef crest } \\
\hline$X$ vs $Y_{\text {Macroalgae }}$ & 0.49 & 0.32 & 6 & 0.20 & 0.57 & 10 \\
\hline $\mathrm{X}$ vs $\mathrm{Y}_{\text {Turf }}$ & -0.71 & 0.11 & 6 & 0.46 & 0.18 & 10 \\
\hline $\mathrm{X}$ vs $\mathrm{Y}_{\mathrm{CCA}}$ & -0.08 & 0.87 & 6 & 0.13 & 0.72 & 10 \\
\hline \multicolumn{7}{|c|}{ Reef slope } \\
\hline $\mathrm{X}$ vs $\mathrm{Y}_{\text {Macroalgae }}$ & $-0,59$ & 0.12 & 8 & -0.43 & 0.08 & 18 \\
\hline $\mathrm{X}$ vs $\mathrm{Y}_{\text {Turf }}^{\prime}$ & 0.16 & 0.71 & 8 & 0.01 & 0.98 & 18 \\
\hline $\mathrm{X}$ vs $\mathrm{Y}_{\mathrm{CCA}}$ & 0.55 & 0.16 & 8 & 0.53 & $0.02 *$ & 18 \\
\hline
\end{tabular}

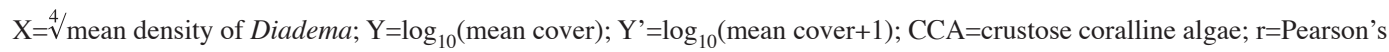
correlation coefficient; $\mathrm{p}=$ probability value; $\mathrm{n}=$ number of sites; $*=$ statistical significance.

country wide pattern of low population density at mid depth reefs; whereas densities recorded at reef crests (this study) are among the highest reported around the Cuban Archipelago (Martín-Blanco et al. 2010). The pattern of higher population density inside the Marine Reserve at studied reefs contrasts with that reported by Harborne et al. (2009) in The Bahamas, where abundances of Diadema were higher outside the Exuma Cays Land and Sea Park. Observed differences in mean densities at reef crests in Jardines de la Reina seem to be the result of 

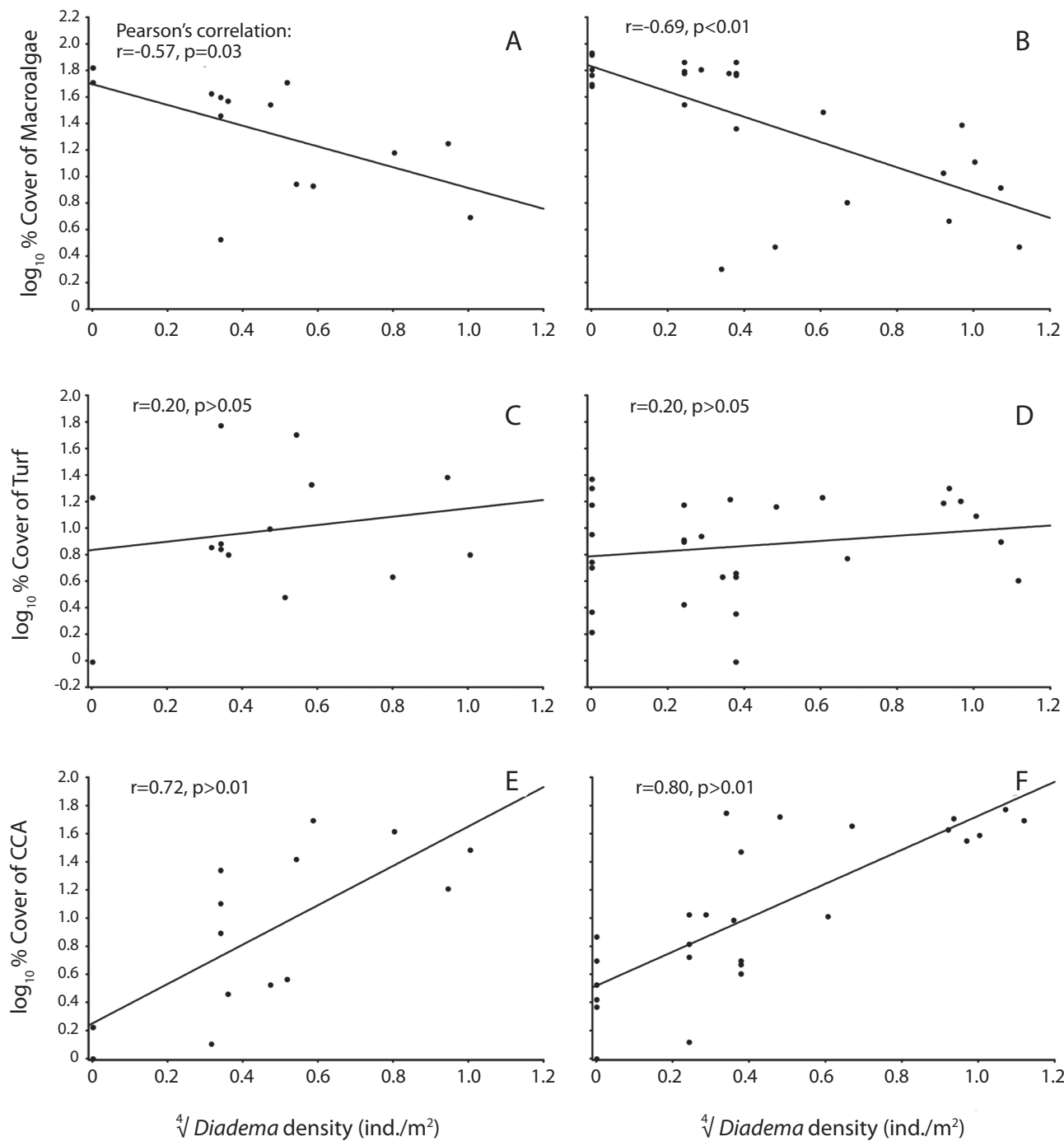

Fig. 4. Relationship between density of $D$. antillarum and percent cover of macroalgae (A, B), algal turf (C, D) and $\mathrm{CCA}=$ crustose coralline algae $(\mathrm{E}, \mathrm{F})$ across all fore reef sites in Jardines de la Reina during the study. Data is presented

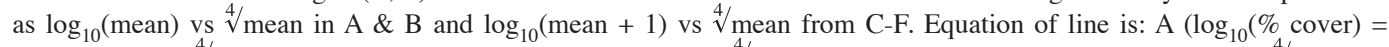
$1.6965-0.7828 \sqrt[4]{\text { density }}), \mathrm{B}\left(\log _{10}(\%\right.$ cover $\left.)=1.8312-0.9530 \sqrt[4]{\text { density }}\right), \mathrm{C}\left(\log _{10}(\%\right.$ cover $\left.)=0.8344+0.3140 \sqrt[4]{\text { density }}\right)$, $\mathrm{D}\left(\log _{10}(\%\right.$ cover $\left.)=0.7871+0.1930 \sqrt[4]{\text { density }}\right), \mathrm{E}\left(\log _{10}(\%\right.$ cover $\left.)=0.2499+1.4013 \sqrt[4]{\text { density }}\right), \mathrm{F}\left(\log _{10}(\%\right.$ cover $)=0.5173$ $+1.2095 \sqrt[4]{\text { density). }}$

local factors regulating recruitment processes rather than those responsible for inadequate larval supply or post-settlement mortality (see Martín-Blanco et al. 2010 for a detailed discussion on abundances and size structure of $D$. antillarum in the studied zone at both habitats).
Our results emphasize the importance of Diadema grazing in top-down processes on reef ecosystems. The associations between algal coverage and the abundance of $D$. antillarum (negative in the case of macroalgae and positive in the case of crustose coralline 
algae) suggest that algal community structure in Jardines de la Reina depends, in part, on the influence of Diadema in an overall scale. Although correlations do not prove causality, there is some evidence that highlights the role of Diadema in the control of macroalgae at surveyed reefs. Considering that the protection inside the reserve has been enhanced through time and no major disturbances have occurred in the area, thus fish assemblages and nutrient concentrations remain unaltered, our data and those reported by Pina-Amargós et al. (2006) are reliable enough to support our interpretations. However, some manipulative experiments should be done to corroborate our inference that Diadema is, at present, an important factor on macroalgal cover at reef slopes.

The excessive abundance of macroalgae at reef slopes seems to be due by the almost complete absence of $D$. antillarum at mid depth reefs, where local densities of this urchin were predominantly low $\left(<0.07 \mathrm{ind} / \mathrm{m}^{2}\right.$ in $95 \%$ of surveyed reef slopes during the study). In addition, the higher dominance of macroalgae (up to $87 \%$ cover) and the scarcity of crustose coralline algae $(<4 \%$ cover as mean value) at this habitat suggest that grazing intensity at reef slopes is under threshold levels required to maintain the algal community in a cropped state. As pointed out by Szmant (2002), when a reef has a high algal standing crop, it can be inferred that in some point in time, the algal production has exceeded the capacity of the heterotrophic community to consume it. In consequence, the level of grazing needed to return to coral dominance would differ dramatically from that needed to maintain the former coral dominated system (Mumby 2009).

Considering values of herbivorous fish biomass (Acanthurids + Scarids) reported by Pina-Amargós et al. (2002) in the studied zone (mean biomass $=31.8 \mathrm{~g} / \mathrm{m}^{2}$ and maximum biomass $=56.7 \mathrm{~g} / \mathrm{m}^{2}$ ) and that dominant macroalgae from reef slopes (Dictyota, Lobophora and Halimeda) are those readily consumed by Diadema (reviewed in Szmant 2002) and less palatable to herbivorous fishes (Hay 1997; Author's pers. observ.), one likely explanation to the lack of herbivory at mid depth reefs in Jardines de la Reina could be the absence of $D$. antillarum at this habitat. Furthermore, since macroalgal cover did not vary among zones (two way ANOVA results with balanced data; Fig. 3 A, B) and results from the additional ANOVA, yielded no differences in macroalgal abundances among all zones (except by percent cover from RW zone which was significantly higher than those from NRW and RE) potential higher abundances of herbivorous fish inside the Marine Reserve (author's pers. observ.) appear to make no difference in macroalgal control inside and outside the Marine Reserve. Parrotfishes and surgeonfishes appear to play a critical role in preventing phase shifts to macroalgae but when presented with intact stands of macroalgae, their ability to remove the algae may be limited (Bellwood et al. 2006). In contrast to Mumby et al. (2007) observations about trophic cascades resulting in reductions of macroalgal cover inside Marine Reserves, positive effects expected from reserve-driven trophic interactions in Jardines de la Reina, via the increase of fish grazing, are not strong enough to prevent macroalgal overgrowth and enhance coral recruitment at mid depth reefs in the largest of Caribbean Marine Reserves. Neither highly diverse fish assemblages and mature food webs, nor the presence of abundant herbivorous fish in Jardines de la Reina Marine Reserve appear to increase resilience at surveyed reef slopes without suitable functional redundancy in the absence of $D$. antillarum at the time of this study.

Similar results have been reported from other Cuban reefs at the same depth; Guardia et al. (2004a) recorded high percentages of macroalgae from diving sites in Maria $\mathrm{La}$ Gorda, southwestern end of Cuba ( $\approx 50 \%$ from spoor and grove and patch reefs sites) and a high dominance of Dictyota and Lobophora at all over the reef; patterns that seem to be associated, as mentioned by the authors, with the significant scarcity of $D$. antillarum. Present results are also into conformity to that obtained by Williams \& Polunin (2001) at several locations in the Caribbean, including two 
locations from the Isle of Youth, Southwestern Cuba (a Marine Reserve at Punta Francés and a non protected zone at Punta del Este). Their findings indicate that, even in locations where herbivorous fish are abundant (mean biomass $=9.3 \mathrm{~g} / \mathrm{m}^{2}$ ) there is an upper limit to the amount of substrate that can be grazed with sufficient intensity for upright macroalgae to be excluded in the absence of Diadema; suggesting that those reefs would previously have been dependent on Diadema grazing. The fact that mean biomass of herbivorous fish reported by Pina-Amargós et al. (2002) at the studied zone in Jardines de la Reina was three times higher than average biomass reported by Williams \& Polunin (2001) and that coral reefs from Jardines de la Reina still show higher percentages of macroalgae, suggest that the role of $D$. antillarum in the control of macroalgae needs to be considered when analyzing algal community structure in Jardines de la Reina coral reefs. Results from the North coast of Havana (H.P. Caballero 2007, pers. comm.) reinforce this idea since percent covers of macroalgae (24-67\%) recorded from reef slopes, where abundances of Diadema reach up to 0.63ind/ $\mathrm{m}^{2}$ and fish assemblages are highly affected by overfishing (mean overall fish biomass $=4 \mathrm{~g}$ / $\mathrm{m}^{2}$ and mean herbivorous fish biomass $=1.7 \mathrm{~g} /$ $\mathrm{m}^{2}$; H.P. Caballero 2007, pers. comm.), are comparatively lower than those recorded in Jardines de la Reina at the same habitat (29-87\%; this study). In addition, algal species composition from the North coast of Havana contrasts with that from Jardines de la Reina; as CleroAlonso 2007 (pers. comm.) the abundance of filamentous algae in Havanan reefs, specially Cladophora and Cladophoropsis, is higher than that observed in Jardines de la Reina, where they are rare, what illustrate different components of herbivory between locations and highlights the higher intensity of Diadema grazing in the North coast of Havana, where not only macroalgal species preferred by this urchin are less abundant, but also the percent cover of the entire macroalgal community. However, different biophysical conditions from northern reefs (e.g. different wave exposure) should be considered for generalizations regarding differential effects on algal communities independently of urchin grazing.

On the other hand, partial correlations with data recorded from reef crests and reef slopes by separate, indicate no significant associations between algal coverage and the abundance of $D$. antillarum at this spatial scale. Data from reef crests suggest that algal community structure at this habitat is being shaped by the synergistic action of other factors (e.g. fish grazing) rather than the influence of Diadema grazing alone. If we consider average biomass of herbivorous fish $\left(86.6 \mathrm{~g} / \mathrm{m}^{2}\right)$ reported by Pina-Amargós et al. (2002) from reef crests in Jardines de la Reina and that abundances of upright macroalgae at this habitat are naturally limited by physical factors (e.g. wave action), we cannot discount the role of fish grazing as a key component of herbivory at these sites. Certainly, in shallow reefs, where herbivorous fish are more abundant, grazing by fishes alone can maintain the algal community in a cropped state (Carpenter 1986, Lewis 1986, Bruggemann et al. 1994). Nevertheless, we observed clear signs of Diadema grazing at shallow reefs (large patches of bare substrate around Diade$m a$ aggregations and sparse macroalgal cover), where urchin abundances were moderately high (up to $1.553 \mathrm{ind} / \mathrm{m}^{2}$ ) and percent covers of algae preferred by Diadema were very low $(<6 \%)$. Additionally, current abundances of macroalgae at reef crests in Jardines de la Reina $(<10 \%$ cover) are comparatively lower than those reported by Pina-Amargós et al. (2006) at the studied area (32\% cover; average values from data recorded in 2001), what suggests, together with recent observations of new recruits of $A$. palmata (F. Pina-Amargós 2010, pers. comm.), that grazing intensity have increased at the same time that Diadema recruitment began to be noticeable $(\approx 3-4$ years before our surveys took place; Martín-Blanco et al. 2010).

Although our results cannot explain the relative importance of Diadema grazing and correlation evidence do not prove a cause and effect hypothesis, the recovery of D. antillarum across the Caribbean and its association with 
reduced macroalgal cover and enhanced coral recruitment at shallow reefs (Miller et al. 2003, Weil et al. 2005, Carpenter \& Edmunds 2006, Myhre \& Acevedo-Gutiérrez 2007) along with prior experimental studies (Ogden et al. 1973, Sanmarco et al. 1974, Carpenter 1981, 1986, Sanmarco 1980, 1982), support our hypothesis on the functional role of $D$. antillarum in mediating the removal of macroalgae at surveyed reefs. However, further experimental studies should be addressed to determine the importance of Diadema grazing and fish grazing by separate in order to improve our understanding about the structure and functioning of these ecosystems in which three dimensional structure of coral assemblages still persists. Since assemblages of reef fish and sea urchins are highly dependent on three dimensional structure of reef habitats (Hixon \& Beets 1993, Aguilar et al. 1997, González-Sansón et al. 1997, Friedlander \& Parrish 1998, Jones et al. 2004, Idjadi \& Edmunds 2006, Lee 2006) and fish/urchin grazing reduces macroalgal cover and promotes coral recruitment which in turn can help to maintain three dimensional structure (Aronson \& Precht 2000, Bellwood et al. 2004, Carpenter \& Edmunds 2006, Mumby 2006, 2009, Mumby et al. 2006, Mumby et al. 2007), positive feed backs resulting in coral community recovery might be expected to occur in Jardines de la Reina as Diadema populations continue to increase and the reserve gets older for cascading interactions to be effective. Considering that conservation driven processes contributing to coral reef ecosystems recovery may take long periods of time to be effective (McClanahan 2000, Rodwell et al. 2003, Russ \& Alcala 2004, McClanahan et al. 2005, 2007) and that recovery of $D$. antillarum is still limited to shallow depths in Jardines de la Reina, additional management actions such as restoration programs should be implemented in favor of those reefs where urchin populations are scarce and macroalgal occupied space limits coral recruitment, specially at reef slopes.

\section{ACKNOWLEDGMENTS}

The authors are thankful to the staff of Azulmar for logistical support on Jardines de la Reina, specially to Giuseppe Omegna (Pepe) its manager and Noel López. To WWF Canada for funding this research and to E. Sala, Director of the Center for Marine Biodiversity and Conservation of the Scripps Institution of Oceanography, for partial funding and logistics. We thank the Ministry of Science, Technology and Environment for funds and logistics, especially C. Pazos Alberdi, R. Gómez Fernández, A. Zúñiga Ríos. Infinite thanks to CIEC's staff for supporting us in doing research on Jardines de la Reina, specially to L. Hernández Fernández, A. Zayas Fernández, W. Acosta de la Red, A. Jiménez del Castillo, M. Lazarte Llanes. We also want to thanks P.M. Alcolado, H.P. Caballero, Y. Lezcano, for assistance in bibliography and especial considerations.

\section{RESUMEN}

A pesar de la importancia del forrageo de Diadema en la estructuración de los arrecifes de coral, la información disponible sobre la actual abundancia de algas y de las interacciones de erizos en Cuba es escasa. Por lo tanto, se analizan las variaciones espaciales en la abundancia de Diadema antillarum y su influencia sobre las algas en 22 arrecifes en Jardines de la Reina, en junio/2004 y abril/2005. Los erizos se muestrearon en recorridos de $30 \times 2 \mathrm{~m}(5 /$ sitio) y las algas en cuadrículas de $0.25 \mathrm{~m}$ de lado (15/sitio). Las densidades de Diadema fueron mayores en las crestas arrecifales $\left(0.013-1.553 \mathrm{ind} / \mathrm{m}^{2}\right)$ mientras que las pendientes mostraron valores hasta tres ordenes de magnitud menor y presentaron un cubrimiento excesivo de macroalgas (hasta 87\%), siendo las más abundantes Dictyota, Lobophora y Halimeda. Las densidades de erizos estuvieron correlacionadas negativa y positivamente con el cubrimiento de macroalgas y algas costrosas, respectivamente, en el análisis global, pero no en hábitats separados (especialmente en crestas), sugiriendo, conjuntamente con la biomasa histórica de peces, que la estructura de las comunidades en las crestas está determinada por la acción sinérgica de otros factores (herbivoría de peces) más que por la influencia de Diadema solo. No obstante, se observaron indicios del forrajeo de Diadema, y el cubrimiento de macroalgas disminuyó desde 2001, lo cual sugiere que la 
intensidad de la herbivoría aumentó al mismo tiempo que el reclutamiento de Diadema.

Palabras clave: Diadema antillarum, estructura de las comunidades de algas, relaciones alga-erizo, herbivoría, Jardines de la Reina, Cuba.

\section{REFERENCES}

Aguilar, C., G. González-Sanasón, J. Angulo \& C. González. 1997. Variación espacial y temporal de la ictiofauna en un arrecife de coral costero de la región noroccidental de Cuba. I: Abundancia total. Rev. Invest. Mar. 18: 223-232.

Alcolado, P.M., R. Claro, B. Martínez-Daranas, G. Menéndez-Macía, P. García-Parrado, K. Cantelar, M. Hernández \& R. del Valle. 2001. Evaluación ecológica de los arrecifes coralinos del oeste de Cayo Largo del Sur, Cuba: 1998-1999. Bol. Invest. Mar. Costeras 30: $25-32$.

Alcolado, P.M., D. Hernández-Muñoz, H.P. Caballero, L. Busutil, S. Perera \& G. Hidalgo. 2009. Efectos de un inusual período de alta frecuencia de huracanes sobre el bentos de arrecifes coralinos. Rev. Cienc. Mar. Costeras 1: 73-94.

Appeldoorn, R.C. \& K.C. Lindeman. 2003. A Caribbeanwide survey of marine reserves: spatial coverage and attributes of effectiveness. Gulf. Caribb. Res. 14: $139-154$

Aronson, R.B. \& W.F. Precht. 2000. Herbivory and algal dynamics on the coral reef at Discovery Bay, Jamaica. Limnol. Oceanogr. 45: 251-255.

Aronson, R.B. \& W.F. Precht. 2006. Conservation, precaution, and Caribbean reefs. Coral Reefs 25: 441-450.

Bellwood, D.R., T.P. Hughes, C. Folke \& M. Nyström. 2004. Confronting the coral reef crisis. Nature 429 : 827-833.

Bellwood, D.R., T.P. Hughes \& A.S. Hoey. 2006. Sleeping functional group drives coral-reef recovery. Curr. Biol. 16: 2434-2439.

Bruggemann, J.H., M.J.H. Vanoppen \& A.M. Breeman. 1994. Foraging by the stoplight parrotfish Sparisoma viride I. Food selection in different socially determined habitats. Mar. Ecol. Prog. Ser. 106: 41-55.

Caballero, H.P. \& E. de la Guardia. 2003. Arrecifes de coral utilizados como zonas de colectas para exhibiciones en el Acuario Nacional de Cuba. I. Costa noroccidental de la Habana, Cuba. Rev. Invest. Mar. 24: $205-220$.
Caballero, H.P., D. Rosales \& A. Alcalá. 2006. Estudio diagnóstico del arrecife coralino del Rincón de Guanabo, Ciudad de la Habana, Cuba. I. Corales, esponjas y gorgonáceos. Rev. Invest. Mar. 27: 49-59.

Caballero, H.P., P.M. Alcolado \& A. Semidey. 2009. Condición de los arrecifes de coral frente a costas con asentamientos humanos y aportes terrígenos: el caso del litoral habanero, Cuba. Rev. Cienc. Mar. Costeras 1: 49-72.

Carpenter, R.C. 1981. Grazing by Diadema antillarum Philippi and its effects on the benthic algal community. J. Mar. Res. 39: 747-765.

Carpenter, R.C. 1986. Partitioning herbivory and its effects on coral reef algal communities. Ecol. Monogr. 56: 345-36.

Carpenter, R.C. 1990. Mass mortality of Diadema antillarum I. Long-term effects on sea urchin populationdynamics and coral reef algal communities. Mar. Biol. 104: 67-77.

Carpenter, R.C. \& P.J. Edmunds. 2006. Local and regional scale recovery of Diadema promotes recruitment of scleractinian corals. Ecol. Lett. 9: 271-280.

Clero-Alonso, L., F. Pina-Amargós, L. Hernández-Frenández, F. Martín-Blanco, D. Zúñiga-Ríos, S. Cowling, A.K. Brady \& S. Caldwell. 2006. Biota acuática del norte de la provincia de Ciego de Ávila, p. 182-206. In F. Pina-Amargós (ed.). Ecosistemas costeros: biodiversidad y gestión de los recursos naturales. Compilación por el XV Aniversario del Centro de Investigaciones de Ecosistemas costeros (CIEC). CUJAE, Ciudad de la Habana, Cuba.

De Ruyter van Steveninck, E.D. \& A.M. Breeman. 1987. Deep water populations of Lobophora variegata (Phaeophyceae) on the coral reef of Curaçao: influence of grazing and dispersal on distribution patterns. Mar. Ecol. Prog. Ser. 38: 241-250.

Edmunds, P.J. \& R.C. Carpenter. 2001. Recovery of Diadema antillarum reduces macroalgal cover and increases abundance of juvenile corals on a Caribbean reef. P. Natl. Acad. Sci. USA. 98: 5057-5071.

Friedlander, A.M. \& J.D. Parrish. 1998. Habitat characteristics affecting fish assemblages on a Hawaiian coral reef. J. Exp. Mar. Biol. Ecol. 224: 1-30.

Guardia, E., A.P. Valdivia \& P. González-Díaz. 2004a. Estructura de las comunidades bentónicas en la zona de buceo de María La Gorda, Ensenada de Corrientes, Sureste de la Península de Guanahacabibes, Cuba. Rev. Invest. Mar. 25: 103-111. 
Guardia, E., P. González-Díaz \& S. Castellanos-Iglesias. 2004b. Estructura de la comunidad de grupos bentónicos sésiles en la zona de buceo de Punta Francés, Cuba. Rev. Invest. Mar. 25: 81-90.

Guardia, E., P. González-Díaz, A. Valdivia \& O. GonzálezOntivero. 2006. Estructura y salud de la comunidad de corales en el arrecife de la zona de buceo de Cayo Levisa, Archipiélago Los Colorados, Cuba. Rev. Invest. Mar. 27: 197-208.

González-Sansón, G., C. Aguilar, J. Angulo \& C. González. 1997. Variación espacial y estacional de la ictiofauna en un arrecife de coral costero de la region noroccidental de Cuba. II: Diverisdad. Rev. Invest. Mar. 18: 233-240.

González de Zayas, R., A. Zúñiga-Ríos, O. Camejo-Cardoso, L.M. Batista-Tamayo \& R. Cárdenas-Murillo. 2006. Atributos físicos del ecosistema Jardines de la Reina, p. 296-351. In F. Pina-Amargós (ed.). Ecosistemas costeros: biodiversidad y gestión de los recursos naturales. Compilación por el XV Aniversario del Centro de Investigaciones de Ecosistemas Costeros (CIEC). CUJAE, Ciudad de la Habana, Cuba.

Harborne, A.R., P.G. Renaud, E.H.M. Tyler \& P.J. Mumby. 2009. Reduced density of the herbivorous urchin Diadema antillarum inside a Caribbean marine reserve linked to increased predation pressure by fishes. Coral Reefs 28: 783-791.

Hay, M.E. 1997. The ecology and evolution of seaweedsherbivores interactions on coral reefs. Coral Reefs 16: $67-76$.

Herrera-Moreno, A., E. Valdés-Muñoz \& D. Ibarzábal. 1981. Evaluación poblacional del erizo negro, Diadema antillarum Phillipi, mediante un diseño de muestreo aleatorio estratificado, y algunos aspectos de su biología. Cienc. Biol. 6: 61-79.

Hixon, M.A. \& J.P. Beets. 1993. Predation, prey refuges, and the structure of coral-reef fish assemblages. Ecol. Monogr. 63: 77-101.

Hughes, T.P. 1994. Catastrophes, phase shifts and largescale degradation of a Caribbean coral reef. Science 265: $1547-1551$

Hughes, T.P., B.D. Keller, J.B.C. Jackson \& M.J. Boyle. 1985. Mass mortality of the echinoid Diadema antillarum Philippi in Jamaica. Bull. Mar. Sci. 36: $377-384$

Hughes, T.P., A.M. Szmant, R. Steneck, R. Carpenter \& S. Miller. 1999. Algal blooms on coral reefs: What are the cause? Limnol. Oceanogr. 44: 1583-1586.
Idjadi, J.A. \& P.J. Edmunds. 2006. Scleractinian corals as facilitators for other invertebrates on a Caribbean reef. Mar. Ecol. Prog. Ser. 319: 117-127.

Jones, G.P., M.I. McCormick, M. Srinivasan \& J.V. Eagle. 2004. Coral decline threatens fish biodiversity in marine reserves. P. Natl. Acad. Sci. USA. 101: 8251-8253.

Knowlton, N. 2001. Sea urchin recovery from mass mortality: New hope for Caribbean coral reefs? P. Natl. Acad. Sci. USA. 98: 4822-4824.

Lee, S.C. 2006. Habitat complexity and consumer-mediated positive feedbacks on a Caribbean coral reef. Oikos 112: 442-447.

Levitan, D.R. 1988. Algal-urchin biomass responses following the mass mortality of Diadema antillarum Philippi at St. John. J. Exp. Mar. Biol. Ecol. 119: $167-178$.

Lewis, S.M. 1986. The role of herbivorous fishes in the organization of a Caribbean reef community. Ecol. Monogr. 56: 183-200.

Liddell, W.D. \& S.L. Ohlhorst. 1986. Changes in benthic community composition following the mass mortality of Diadema at Jamaica. J. Exp. Mar. Biol. Ecol. 95: 271-278.

Martín-Blanco, F., G. González-Sansón, F. Pina-Amargós \& L. Clero-Alonso. 2010. Abundance, distribution and size structure of Diadema antillarum (Echinodermata: Diadematidae) in South Eastern Cuban coral reefs. Rev. Biol. Trop. 58: 663-676.

McClanahan, T.R. 2000. Recovery of the coral reef keystone predator, Balistapus undulatus, in East African marine parks. Biol. Conserv. 94: 191-198.

McClanahan, T.R. \& N.A.J. Graham. 2005. Recovery trajectories of coral reef fish assemblages within Kenyan marine protected areas. Mar. Ecol. Prog. Ser. 294: 241-248.

McClanahan, T.R., N.A.J. Graham, J.M. Calnan \& M.A. MacNeil. 2007. Toward pristine biomass: Reef fish recovery in coral reef marine protected areas in Kenya. Ecol. Appl. 17: 1055-1067.

Miller, J.R., A.J. Adams, N.B. Ogden, J.C. Ogden \& J.P. Ebersole. 2003. Diadema antillarum 17 years after mass mortality: is recovery beginning on St. Croix? Coral Reefs 22: 181-187.

Mumby, P.J. 2006. The impact of exploiting grazers (Scaridae) on the dynamics of caribbean coral reefs. Ecol. Appl. 16: 747-769. 
Mumby, P.J. 2009. Phase shifts and the stability of macroalgal communities on Caribbean coral reefs. Coral Reefs 28: 761-773.

Mumby, P.J., J.D. Hedley, K. Zychaluk, A.R. Harborne \& P.G. Blackwell. 2006. Revisiting the catastrophic dieoff of the urchin Diadema antillarum on Caribbean coral reefs: Fresh insights on resilience from a simulation model. Ecol. Model. 196: 131-148.

Mumby, P.J., A.R. Harborne, J. Williams, C.V. Kappel, D.R. Brumbaugh, F. Micheli, K.E. Holmes, C.P. Dahlgren, C.B. Paris \& P.G. Blackwell. 2007. Trophic cascade facilitates coral recruitment in a marine reserve. P. Natl. Acad. Sci. USA. 104: 8362-8367.

Myhre, S. \& A. Acevedo-Gutiérrez. 2007. Recovery of sea urchin Diadema antillarum populations is correlated to increased coral and reduced macroalgal cover. Mar. Ecol. Prog. Ser. 329: 205-210.

Ogden, J.C., R.A. Brown \& N. Salesky. 1973. Grazing by the echinoid Diadema antillarum Philippi: formation of halos around West Indian patch reefs. Science 182: $715-717$

Pina-Amargós, F. 2008. Efectividad de la Reserva Marina de Jardines de la Reina en la conservación de la ictiofauna. Tesis de Doctorado, Universidad de La Habana, Ciudad de la Habana, Cuba.

Pina-Amargós, F., P.M. Alcolado, L. Hernández-Fernández, G. González-Sansón, R. González de Zayas, L. Clero-Alonso, K. Cantelar-Ramos \& S. González-Ferrer. 2002. Estado de salud de los arrecifes coralinos de Jardines de la Reina. Resultado: Caracterización de los arrecifes coralinos de Jardines de la Reina, p. 1-20. In F. Pina-Amargós (ed.). Caracterización y manejo de los ecosistemas marinos en el archipiélago Jardines de la Reina (Informe Final de Proyecto). Centro de Investigaciones de Ecosistemas Costeros (CIEC), Cayo Coco, Ciego de Ávila, Cuba.

Pina-Amargós, F., L. Clero-Alonso, F. Martín-Blanco, L. Hernández-Frenández, W. Acosta de la Red, L.
Cabreja-Ávila, P.M. Alcolado, R.M. Claro, K.R. Cantelar, S.F. González \& J.P.G. Artiaga. 2006. Biota marina del ecosistema Jardines de la Reina, p. 396449. In F. Pina-Amargós (ed.). Ecosistemas costeros: biodiversidad y gestión de los recursos naturales. Compilación por el XV Aniversario del Centro de Investigaciones de Ecosistemas Costeros (CIEC). CUJAE, Ciudad de la Habana, Cuba.

Rodwell, L.D., E.B. Barbier, C.M. Roberts \& T.R. McClanahan. 2003. The importance of habitat quality for marine reserve fishery linkages. Can. J. Fish. Aquat. Sci. 60: 171-181.

Russ, G.R. \& A.C. Alcala. 2004. Marine reserves: longterm protection is required for full recovery of predatory fish populations. Oecologia 138: 622-627.

Sanmarco, P.W. 1980. Diadema and its relationship to coral spot mortality: grazing, competition and biological disturbance. J. Exp. Mar. Biol. Ecol. 45: 245-272.

Sanmarco, P.W. 1982. Effects of grazing by Diadema antillarum Philippi (Echinodermata: Echinoidea) on algal diversity and community structure. J. Exp. Mar. Biol. Ecol. 65: 83-105.

Sanmarco, P.W., J.S. Levinton \& J.C. Ogden. 1974. Grazing and control of coral reef community structure by Diadema antillarum (Echinodermata: Echinoidea): a preliminary study. J. Mar. Res. 32: 47-53.

Szmant, A.M. 2002. Nutrient enrichment on coral reefs: Is it a major cause of coral reef decline? Estuaries 25: 743-766.

Weil, E., J.L. Torres \& M. Ashton. 2005. Population characteristics of the sea urchin Diadema antillarum in La Parguera, Puerto Rico, 17 years after the mass mortality event. Rev. Biol. Trop. 53: 219-231.

Williams, I.D. \& N.V.C. Polunin. 2001. Large-scale associations between macroalgal cover and grazer biomass on mid-depth reefs in the Caribbean. Coral Reefs 19: 358-366. 